Bartosz Łukowiak*

ORCID: 0000-0003-3993-2182

Uniwersytet Wrocławski

https://doi.org/10.19195/1733-5779.33.2

\title{
Przedawnienie straty podatkowej - uwagi na tle wyroku Wojewódzkiego Sądu Administracyjnego we Wrocławiu z dnia 15 lutego 2018 roku, I SA/Wr 462/17**
}

JEL Classification: K2, K4, K34

Słowa kluczowe: przedawnienie straty podatkowej, przedawnienie, strata podatkowa, prawo podatkowe, sądownictwo administracyjne

Keywords: limitation of tax loss, limitation, tax loss, tax law, administrative judiciary

Abstrakt: Przedmiotem niniejszej pracy jest zagadnienie przedawnienia straty podatkowej. Podstawę rozważań stanowi treść wyroku Wojewódzkiego Sądu Administracyjnego we Wrocławiu z dnia 15 lutego 2018 roku, I SA/Wr 462/17, w którym przyjęto, że art. 70 § 1 Ordynacji podatkowej należy stosować nie tylko w odniesieniu do przedawnienia zobowiązania podatkowego, lecz także przedawnienia straty podatkowej. W tekście przeprowadzono szczegółową analizę przywołanego orzeczenia, przedstawiono dalsze argumenty na rzecz stanowiska zaprezentowanego w jego uzasadnieniu oraz sformułowano stosowne wnioski de lege ferenda.

\section{Limitation of tax loss - comments on the background of the judgment of the Provincial Administrative Court in Wrocław of 15 February 2018, I SA/Wr 462/17}

\begin{abstract}
The subject of this work is the issue of the limitation of tax loss. The basis for consideration is the content of the judgment of the Provincial Administrative Court in Wrockaw of 15 February 2018, I SA/Wr 462/17, in which it was assumed that Article 70, § 1 of the Polish Tax Ordinance Act must be applied not only with regard to the limitation of tax liability but also to the limitation of tax loss. The text analyzes the judgment in detail, presents further arguments in favor of the position set out in its statement of reasons and draws the appropriate conclusions de lege ferenda.
\end{abstract}

* Opiekun naukowy (Scientific Tutor) — prof. dr hab. Jerzy Skorupka

** LEX nr 2474926. 


\section{Wstęp}

Wskazany w tytule pracy wyrok dotyczy ram czasowych, w których obrębie możliwe jest rozstrzyganie przez organy podatkowe o prawidłowości straty wykazanej przez podatnika w deklaracji podatkowej za dany rok podatkowy. Przedmiotem postępowania zakończonego tym orzeczeniem była skarga na treść decyzji Dyrektora Izby Administracji Skarbowej we W., utrzymującej w mocy decyzję Naczelnika Urzędu Skarbowego w L., w której organ ten określił skarżącemu wysokość straty w podatku dochodowym od osób fizycznych, poniesionej przez niego z tytułu prowadzenia pozarolniczej działalności gospodarczej, na kwotę inną aniżeli pierwotnie wykazana w sporządzonym przez podatnika zeznaniu podatkowym.

\section{Stan faktyczny}

Zasadniczy spór podatnika z organami podatkowymi obu instancji sprowadzał się do relacji między art. 83a ust. 1 ustawy z dnia 7 września 1991 roku o systemie oświaty ${ }^{1}$ a art. 5a pkt 6 ustawy z dnia 26 lipca 1991 roku o podatku dochodowym od osób fizycznych ${ }^{2}$. Zgodnie z pierwszym z tych przepisów prowadzenie placówki związanej z wychowaniem przedszkolnym nie jest uznawane za przejaw działalności gospodarczej ${ }^{3}$. Z kolei druga z regulacji definiuje działalność gospodarczą (a także pozarolniczą działalność gospodarczą) na potrzeby opodatkowania podatkiem dochodowym od osób fizycznych, przy czym definicja ta nie odnosi się w żadnej mierze do ujęć owej działalności spotykanych na gruncie innych ustaw $^{4}$. Tym samym organy podatkowe uznały, że na potrzeby prowadzonego przez nie postępowania podatkowego miarodajna jest jedynie okoliczność, że praktykowany przez skarżącego sposób zarobkowania spełnia przesłanki uznania go za działalność gospodarczą w rozumieniu ustawy podatkowej, przez co do-

1 Dz.U. z 2016 r. poz. 1943.

2 Dz.U. z 2019 r. poz. 1387, 1394, 1622, 1726 i 1835 (dalej: u.p.d.o.f.).

${ }^{3}$ Przepis ten został uchylony na mocy art. 15 pkt 119 ustawy z dnia 14 grudnia 2016 roku Przepisy wprowadzające ustawę — Prawo oświatowe, Dz.U. z 2017 r. poz. 60 z późn. zm., jednakże obecnie obowiązujący w tym zakresie art. 170 ust. 1 ustawy z dnia 14 grudnia 2016 roku Prawo oświatowe, Dz.U. z 2019 r. poz. 1148 z późn. zm., jest jego niemal wiernym powtórzeniem.

${ }^{4} \mathrm{~W}$ przeciwieństwie na przykład do definicji działalności gospodarczej znanej z art. 3 pkt 9 ustawy z dnia 29 sierpnia 1997 roku — Ordynacja podatkowa, Dz.U. z 2019 r. poz. 900 z późn. zm. (dalej: o.p.), w którym expressis verbis przesądzono, że daną działalność należy na gruncie tej ustawy uznawać za działalność gospodarczą „nawet gdy inne ustawy nie zaliczają tej działalności do działalności gospodarczej lub osoby wykonującej taką działalność — do przedsiębiorców"; więcej na temat pojęcia działalności gospodarczej w prawie podatkowym zob. P. Borszowski, Działalność gospodarcza w konstrukcji prawnej podatku, Warszawa 2010, passim; idem, Pojęcie działalności gospodarczej w przepisach prawnopodatkowych, „Przegląd Podatkowy” 2007, nr 12, s. $37-42$. 
chody uzyskiwane przez niego z tytułu prowadzenia niepublicznego przedszkola należy traktować jako przychody, o których mowa w art. 10 ust. 1 pkt 3 u.p.d.o.f., a w konsekwencji uwzględnić je w treści przeznaczonego dla podatników prowadzących pozarolniczą działalność gospodarczą zeznania podatkowego. Przyjęcie tego poglądu doprowadziło do uznania wykazanego przez podatnika przychodu, jak również kosztów jego uzyskania, za nieprawidłowe, a w dalszej kolejności do wydania decyzji ustalającej prawidłową — zdaniem organów podatkowych wysokość straty poniesionej przez skarżącego w 2010 roku, to jest decyzji, o której mowa w art. 24 o.p. Do kwestii relacji występującej między wskazanymi wcześniej przepisami nie odniósł się Wojewódzki Sąd Administracyjny we Wrocławiu (dalej: WSA we Wrocławiu lub sąd), w związku z czym nie zostanie ona bardziej rozwinięta również w niniejszej pracy.

Co jednak istotniejsze, w treści decyzji o utrzymaniu w mocy rozstrzygnięcia organu pierwszej instancji Dyrektor Izby Administracji Skarbowej we W. odniósł się także do możliwości orzekania przez niego o wysokości straty poniesionej w 2010 roku po upływie terminu przedawnienia zobowiązania podatkowego za ten rok podatkowy. Zdaniem organu odwoławczego strata podatkowa jest „elementem kalkulacyjnym podatku w następujących po sobie kolejnych pięciu latach podatkowych, w których jest odliczana, a nie zobowiązaniem podatkowym za dany rok, w którym wystąpiła”, co według organu prowadzi do wniosku, że nieuprawnione jest mówienie o przedawnieniu samej straty (ściślej: przedawnieniu prawa do jej określenia w drodze decyzji administracyjnej5), skoro mimo jej poniesienia w 2010 roku można ją odliczyć również w latach następnych, to jest aż do 2015 roku$^{6}$.

W nadesłanej do WSA we Wrocławiu skardze podatnik kwestionował w głównej mierze wskazane ustalenia organu związane z kwestią możliwości zaliczenia prowadzonej przez niego działalności jako działalności gospodarczej, jednakże — już w toku postępowania sądowoadministracyjnego — ze względu na wydanie w tym czasie przez Naczelny Sąd Administracyjny (dalej: NSA) wskazanej już wcześniej uchwały z dnia 6 listopada 2017 roku w sprawie II FPS 3/17 pełnomocnik skarżącego zarzucił decyzji organu drugiej instancji także naruszenie przepisów dotyczących przedawnienia zobowiązań podatkowych. Zauważył, że orzekanie o prawidłowości zadeklarowanej straty po upływie okresu przedaw-

5 Na rozróżnienie to zwraca się uwagę w szczególności w zdaniu odrębnym do uchwały NSA (7) z dnia 6 listopada 2017 roku, II FPS 3/17, ONSA i WSA 2018, nr 2, poz. 21, s. 29.

6 Tak też L. Etel, [w:] Ordynacja podatkowa. Komentarz, red. L. Etel, Warszawa 2017, s. 593594, którego zdaniem decyzja określająca wysokość straty może zostać wydana w okresie 5 lat od końca roku kalendarzowego, w którym upłynął pięcioletni okres przedawnienia zobowiązania podatkowego, a zatem — łącznie — w terminie dziesięciu lat; podobnie B. Gruszczyński, [w:] S. Babiarz et al., Ordynacja podatkowa. Komentarz, Warszawa 2015, s. 258-259. 
nienia zobowiązania, z którego owa strata wynikła ${ }^{7}$, należy uznać za niezgodne z prawem, a w konsekwencji zaskarżoną decyzję uchylić i umorzyć postępowanie podatkowe.

\section{Rozstrzygnięcie WSA we Wrocławiu}

Rozpoznający tę skargę WSA we Wrocławiu podzielił stanowisko skarżącego. Uznał, że orzekanie o prawidłowości zadeklarowanej straty w opisanych okolicznościach jest ze swej istoty bezprawne. W uzasadnieniu swoich wywodów odwołał się przede wszystkim do wskazanej uchwały NSA. Wyjaśnił, że przedawnienie jest jedną z podstawowych instytucji prawa podatkowego, której celem jest przede wszystkim pewność obrotu, w związku z czym wydłużanie okresów przedawnienia w drodze wykładni rozszerzającej należy uznać za niedopuszczalne. Wskazał, iż odczytując art. 70 § 1 o.p. wyłącznie przy użyciu metod wykładni językowej, należałoby stwierdzić, że przepis ten rzeczywiście odnosi się jedynie do przedawnienia zobowiązań podatkowych, nie zaś straty podatkowej ${ }^{8}$, jednakże w sposób jednoznaczny i stanowczy odrzucił możliwość przyjęcia takiego stanowiska. Podniósł, że strata podatkowa nie jest zobowiązaniem podatkowym jako takim ani też „ujemnym zobowiązaniem podatkowym” czy wreszcie „odwrotnością zobowiązania podatkowego", a zatem jeżeli przedawnia się zobowiązanie główne, to — a maiori ad minus — przedawniają się też wszelkie prawa i obowiązki towarzyszące mu lub z nim związane.

Nawiązując do problematyki tak zwanej wykładni prokonstytucyjnej ${ }^{9}$, sąd wskazał, że zaproponowany przez organy podatkowe obu instancji sposób rozumienia art. $70 \S 1$ w zw. z art. 24 o.p. godziłby w wyrażoną w art. 32 ust. 1 Konstytucji RP zasadę równości, zgodnie z którą „wszystkie podmioty prawa [...] charakteryzujące się daną cechą istotną (relewantną) w równym stopniu mają być traktowane równo, a więc według jednakowej miary, bez zróżnicowań zarówno

7 Gwoli ścisłości należy zaakcentować, że skoro w danym roku podatkowym koszty uzyskania przychodu przekroczyły uzyskany przez podatnika przychód, to w omawianej sytuacji nie może być mowy o zobowiązaniu podatkowym w rozumieniu art. 5 o.p., które — właśnie ze względu na ujemny bilans wskazanych wartości — w ogóle nie powstało (R. Mastalski, Prawo podatkowe, Warszawa 2018, s. 407). Jednak, dla uproszczenia dalszych wywodów, stosunek prawnopodatkowy wynikający z powstałej straty nazywany będzie — w ślad zresztą za WSA we Wrocławiu — też zobowiązaniem podatkowym.

8 Tak wcześniej między innymi NSA w wyroku z dnia 3 września 2013 roku, II FSK 2208/12, „Monitor Podatkowy” 2013, nr 11, poz. 42; oraz w wyroku z dnia 25 stycznia 2012 roku, II FSK 1345/10, LEX nr 1108976; wyrok WSA w Olsztynie z dnia 19 kwietnia 2006 roku, I SA/O1 98/06, LEX nr 283245; wyrok WSA w Gdańsku z dnia 8 stycznia 2008 roku, I SA/Gd 901/07, LEX nr 361965.

${ }^{9}$ Na temat pojęcia wykładni prokonstytucyjnej więcej M. Safjan, [w:] Konstytucja RP, t. 1. Komentarz do art. 1-86, red. M. Safjan, L. Bosek, Warszawa 2016, s. 86 n.; zob. też uchwała SN z dnia 20 czerwca 2000 roku, I KZP 14/00, OSN 2000, nr 7-8, poz. 59. 
dyskryminujących, jak i faworyzujących [...]"10, jak też w wywodzoną z art. 84 Konstytucji RP zasadę powszechności opodatkowania, rozumianą jako kierowany do ustawodawcy zwykłego nakaz opodatkowania wszystkich podatników oparty na jednakowych zasadach ${ }^{11}$, co — zdaniem sądu — dotyczyć powinno także kwestii wygasania wierzytelności przez ich przedawnienie.

Jedynie na marginesie warto zauważyć, że WSA we Wrocławiu posłużył się pewnego rodzaju skrótem myślowym. W treści uzasadnienia swojego orzeczenia wykorzystał pojęcie ,zasada powszechności opodatkowania”, podczas gdy w rzeczywistości — jak wynika chociażby z kontekstu, w którym użyto tego pojęcia - miał na myśli, niejako łącznie, dwie różne normy-zasady ${ }^{12}$, tradycyjnie już uznawane za dwie samodzielne zasady prawa podatkowego, to jest zasadę powszechności opodatkowania oraz zasadę równości opodatkowania ${ }^{13}$ (traktowane nieraz wespół jako elementy składowe zasady II stopnia w postaci zasady sprawiedliwości opodatkowania ${ }^{14}$ ).

W komentowanym wyroku przyjęto, że rozumienie wskazanych tu przepisów jako zezwalających na różnicowanie zasad obliczania terminów przedawnienia prawa do kwestionowania przez organ podatkowy prawidłowości sposobu ustalenia przez podatnika prawnopodatkowych konsekwencji zdarzeń prawnych mających miejsce w danym roku podatkowym, w zależności od tego, czy na koniec danego roku wystąpiło:

1. zobowiązanie podatkowe,

2. dochód zwolniony z podatku czy też

3. strata podatkowa

— należy uznać za naruszające wywodzone z art. 2 Konstytucji RP zasady pewności prawa oraz bezpieczeństwa prawnego.

10 Orzeczenie TK z dnia 9 marca 1988 roku, U 7/87, OTK 1988, nr 1, poz. 1; tak też orzeczenie TK z dnia 20 grudnia 1994 roku, K 8/94, OTK 1994, nr 1, poz. 43, a po wejściu w życie obecnie obowiązującej Konstytucji wyroki TK z dnia: 6 maja 1998 roku, K 37/97, OTK 1998, nr 3, poz. 33; 20 października 1998 roku, K 7/98, OTK 1998, nr 6, poz. 96; 17 maja 1999 roku, P 6/98, OTK 1999, nr 4, poz. 76; 21 września 1999 roku, K 6/98, OTK 1999, nr 6, poz. 117; 4 stycznia 2000 roku, K 18/99, OTK 2000, nr 1, poz. 1; 18 grudnia 2000 roku, K 10/00, OTK 2000, nr 8, poz. 298; dnia 21 maja 2002 roku, K 30/01, OTK-A 2002, nr 3, poz. 32; 22 lutego 2005 roku, K 10/04, OTK-A 2005, nr 2, poz. 17; 18 grudnia 2008 roku, K 19/07, OTK-A 2008, nr 10, poz. 182.

11 Por. R. Mastalski, op. cit., s. 41.

12 Więcej na temat pojęcia normy-zasady oraz zasady prawa w ogólności zob. S. Wronkowska, M. Zieliński, Z. Ziembiński, Zasady prawa. Zagadnienia podstawowe, Warszawa 1974, s. 28-48; S. Wronkowska, Z. Ziembiński, Zarys teorii prawa, Poznań 1997, s. 186 n.; S. Wronkowska, Podstawowe pojęcia prawa i prawoznawstwa, Poznań 2005, s. 110.

13 R. Mastalski, op. cit., s. 40-41.

14 Ibidem; L. Etel, [w:] Prawo podatkowe. Zarys wykładu, red. L. Etel, Warszawa 2013, s. 52. 


\section{W poszukiwaniu innych argumentów}

Stanowisko to należy uznać za jak najbardziej prawidłowe, jednakże ze względu na niewątpliwą kontrowersyjność tego zagadnienia, a także jego różnorodne rozumienie zarówno w judykaturze, jak i wśród przedstawicieli nauki prawa podatkowego warto pokusić się o próbę znalezienia innych jeszcze, niewskazanych przez WSA we Wrocławiu, argumentów przemawiających za jego słusznością.

\subsection{Reguła in dubio pro tributario}

Przede wszystkim wypada zauważyć, że zastosowanie w rozpatrywanej sprawie powinna znaleźć też wyrażona $\mathrm{w}$ art. 2a o.p. reguła in dubio pro tributario, zgodnie z którą niedające się usunąć wątpliwości dotyczące treści przepisów prawa podatkowego należy każdorazowo rozstrzygać na korzyść podatnika. W piśmiennictwie wskazuje się, że omawiana reguła znajdzie zastosowanie „wszędzie tam, gdzie istnieją chociażby dwie różne i prawnie dopuszczalne drogi interpretacji i rozumienia tego samego przepisu prawa podatkowego" ${ }^{15}$, a właśnie z taką sytuacją miał do czynienia rozpoznający sprawę sąd.

Warto przy tym zaakcentować, że bezprzedmiotowe byłoby rozstrzyganie w tym miejscu o tym, czy ze względu na fakt wprowadzenia art. 2a o.p. do porządku prawnego dopiero z dniem 1 stycznia 2016 roku ${ }^{16}$ powinien on znaleźć zastosowanie także do stanów faktycznych zaistniałych przed tą datą. Jak słusznie uznaje się w doktrynie prawa podatkowego, wprowadzenie tej regulacji stanowiło jedynie oficjalne zadekretowanie owej reguły (mające charakter wyłącznie deklaratoryjny). Już wcześniej bezsprzecznie obowiązywała ona w systemie prawnym ${ }^{17}$, a w konsekwencji była stosowana w orzecznictwie sądów administracyjnych ${ }^{18}$ czy $^{17}$ też Trybunału Konstytucyjnego ${ }^{19}$. $\mathrm{Z}$ reguły in dubio pro tributario wywodzi się, że „niejasne regulacje prawne nie mogą być interpretowane na niekorzyść podatnika, ponieważ nie może on ponosić negatywnych konsekwencji nieprecyzyjnego

15 M. Damaz, [w:] Ordynacja podatkowa. Komentarz, red. H. Dzwonkowski, Warszawa 2018, s. 19.

16 Przepis ten został dodany na mocy ustawy z dnia 5 sierpnia 2015 roku o zmianie ustawy — Ordynacja podatkowa oraz niektórych innych ustaw (Dz.U. poz. 1197).

17 M. Damaz, op. cit., s. 19; por. jednak głosy krytyczne wobec wyrażenia reguły in dubio pro tributario bezpośrednio w treści ustawy; tak na przykład A. Gomułowicz, Ekspertyza na temat przedstawionego przez Prezydenta RP projektu ustawy o zmianie ustawy Ordynacja podatkowa w zakresie propozycji ujęcia art. 2 a o.p. (druk 3018), „Zeszyty Prawnicze BAS” 2015, nr 2, poz. 46, s. 39-66.

18 Zob. wyrok NSA z dnia 7 lutego 2012 roku, II FSK 1323/10, LEX nr 1137498; wyrok WSA w Szczecinie z dnia 23 stycznia 2010 roku, I SA/Sz 653/09, LEX nr 559567; wyrok WSA w Gdańsku z dnia 21 grudnia 2010 roku, I SA/Gd 677/10, LEX nr 748000.

19 Zob. wyroki TK z dnia: 29 lipca 2014 roku, P 49/13, OTK-A 2014, nr 7, poz. 79; 18 lipca 2013 roku, SK 18/09, OTK-A 2013, nr 6, poz. 80. 
formułowania przepisów prawa podatkowego przez ustawodawcę"20. Pogląd ten należy uznać za trafny, a przy tym korespondujący z wyrażoną w art. 121 o.p. zasadą budzenia zaufania do organów podatkowych, która w zakresie stosowania przepisów prawa materialnego realizuje się przede wszystkim właśnie w ten sposób, że organ podatkowy nie może rozstrzygać na niekorzyść strony wszelkich dostrzeżonych niejasności w przepisach prawa podatkowego ${ }^{21}$. Co więcej, wskazuje się, że źródeł omawianej zasady należy upatrywać między innymi w art. 2 i 84 Konstytucji RP²2, a zatem w przepisach, na które bezpośrednio powołał się też WSA we Wrocławiu.

\subsection{Zasada legalizmu}

Pozostając w zasięgu regulacji konstytucyjnej, należy podnieść także argument, że zgodnie z wyrażoną art. 7 Konstytucji RP zasadą legalizmu organy władzy publicznej działają wyłącznie na podstawie prawa $\mathrm{i}$ jedynie w jego granicach ${ }^{23}$. Tym samym można twierdzić, że dopóki w przepisach prawa podatkowego nie znajdzie się reguła pozwalająca organom administracji podatkowej na wydawanie decyzji określającej wysokość straty podatkowej również po terminie przedawnienia zobowiązania podatkowego, z którego strata ta wynikła, albo też regulacja zbieżna z niektórymi poglądami wyrażanymi w doktrynie prawa podatkowego ${ }^{24}$, wprowadzająca wynoszący łącznie dziesięć lat sui generis termin przedawnienia prawa do wydawania decyzji w przedmiocie wysokości poniesionej przez podatnika straty, dopóty organom tym nie przysługuje kompetencja do pogarszania sytuacji prawnej podatnika wyłącznie w drodze środków wykładniczych ${ }^{25}$.

\subsection{Zakaz tworzenia uprawnień pozornych}

Prezentowany przez organy podatkowe pogląd należy zestawić też z zakorzenionym w art. 2 Konstytucji RP zakazem tworzenia uprawnień pozornych. Zasadza się ona na słusznym założeniu, że ustawodawcy zwykłemu nie wolno tworzyć konstrukcji normatywnych, które stanowią wyłącznie złudzenie prawa i w konsekwencji dają jedynie pozór ochrony interesów jednostki ${ }^{26}$. Jak trafnie wskazał Trybunał Konstytucyjny w wyroku z dnia 25 listopada 1997 roku $^{27}$ :

20 M. Damaz, op. cit., s. 20.

21 B. Adamiak, [w:] B. Adamiak et al., Ordynacja podatkowa. Komentarz, Wrocław 2004, s. 455 .

22 Tak trafnie M. Damaz, op. cit., s. 19.

${ }^{23}$ Konkretyzacją tej regulacji na gruncie postępowania podatkowego jest art. 120 o.p., który mimo że prima facie ogranicza się wyłącznie do nakazu działania na podstawie prawa (a contrario już nie w jego granicach), w doktrynie rozumiany jest jako swoiste powtórzenie art. 7 Konstytucji RP (tak trafnie B. Adamiak, op. cit., s. 449).

24 Por. przyp. 7.

25 Więcej na temat treści zasady legalizmu zob. P. Tuleja, [w:] Konstytucja RP, t. 1, s. 303.

26 Ibidem, s. 225.

27 K 26/97, OTK 1997, nr 5-6, poz. 64. 
W demokratycznym państwie prawnym stanowienie i stosowanie prawa nie może być pułapką dla obywatela, a obywatel powinien mieć możliwość układania swoich spraw w zaufaniu, iż nie naraża się na niekorzystne skutki prawne swoich decyzji i działań niemożliwe do przewidzenia w chwili podejmowania tych decyzji i działań ${ }^{28}$.

Należy przyjąć, że właśnie z taką sytuacją mielibyśmy do czynienia, gdyby ustawodawca z jednej strony informował podatników o tym, że po upływie określonego $\mathrm{w}$ ustawie czasu nie będą już ponosić negatywnych konsekwencji wynikających z konkretnego zobowiązania podatkowego, a z drugiej strony — niejako tylnymi drzwiami - zezwalałby na ponoszenie takich konsekwencji w zakresie straty wynikającej przecież pierwotnie z tego samego zobowiązania.

\subsection{Interes fiskalny państwa}

Na zakończenie warto dodać, że przyjęcie poglądu o możliwości stosowania art. $70 \S 1$ o.p. — w pewnym stopniu praeter legem — również do ram czasowych wydawania decyzji ustalających stratę w podatku dochodowym bynajmniej nie godzi w wartość tradycyjnie przeciwstawianą interesowi podatnika, a mianowicie w interes fiskalny państwa (ewentualnie jednostki samorządu terytorialnego). Zajęcie omawianego stanowiska nie zmienia przecież faktu, że organy podatkowe w dalszym ciągu dysponują wystarczająco długim, bo co do zasady aż pięcioletnim terminem na zakwestionowanie zadeklarowanej przez podatnika straty.

\section{Wnioski}

Zgodnie z przedstawioną argumentacją wydaje się, że stanowisko zajęte przez WSA we Wrocławiu we wskazanym orzeczeniu należy bezsprzecznie uznać za trafny sposób rozumienia art. $70 \S 1 \mathrm{w}$ zw. z art. 24 o.p. Sposób ten nie tylko wpisuje się w wiele reguł i zasad opartych w dużej mierze na normach konstytucyjnych, lecz także jest optymalnym środkiem prawidłowo zabezpieczającym słuszne interesy podatnika. Warto bowiem odnotować, że interes ten zostanie naruszony w każdym przypadku, w którym podatnik może być — w dodatku przez okres trwający łącznie aż dziesięć lat — obciążany przez organ podatkowymi negatywnymi konsekwencjami związanymi ze stratą dotyczącą wygasłego już zobowiązania podatkowego. Należy wyrazić nadzieję, że przyjęty przez sąd pogląd zostanie zaakceptowany także w literaturze prawnopodatkowej, niemniej jednak dziś uzasadnione wydaje się sformułowanie, w charakterze wniosków de lege ferenda, postulatu wyraźnego unormowania przez ustawodawcę kwestii zakresu temporalnego orzekania przez organy podatkowe o prawidłowości zadeklarowanej przez podatnika straty podatkowej, ponieważ na gruncie obecnie obowiązujących

28 Por. też wyroki TK z dnia: 21 grudnia 1999 roku, K 22/99, OTK 1999, nr 7, poz. 166; 7 lutego 2001 roku, K 27/00, OTK 2001, nr 2, poz. 29; 25 kwietnia 2001 roku, K 13/01, OTK 2001, nr 4, poz. 81; 15 lipca 2013 roku, K 7/12, OTK-A 2013, nr 6, poz. 76. 
przepisów prawnych — częstokroć niejasnych i wyjątkowo skomplikowanych nie może dziwić, że organy te mają nie lada trudności z prawidłową interpretacją przepisów normujących rozważaną tu problematykę.

Odpowiednią metodą rozwiązania omawianego problemu mogłoby być na przykład podzielenie art. 24 o.p. na dwie odrębne jednostki organizacyjne (paragrafy), z których $\S 1$ byłby powtórzeniem obecnie obowiązującej regulacji, podczas gdy $\S 2$ otrzymałby następujące brzmienie: „Wydanie decyzji, o której mowa w $\S 1$, nie może nastąpić po upływie 5 lat od końca roku kalendarzowego, w którym strata ta wystąpiła", z ewentualnym unormowaniem w sposób oddzielny również tych sytuacji, w których podatek rozliczany jest w okresach innych niż roczne, bądź też wprowadzenie w rozdziale 8 o.p. unormowania dotyczącego przedawnienia prawa do ustalenia przez organ podatkowy prawidłowości zadeklarowanej przez podatnika straty. Warto wskazać, że de lege lata istnieją już przecież przepisy dotyczące przedawnienia prawa do wydawania przez organy podatkowe określonej decyzji, które mogłyby być swoistym wzorem dla ustawodawcy, czego przykładem jest choćby art. 118 § 1 o.p., limitujący w czasie możliwość wydawania decyzji o odpowiedzialności podatkowej osoby trzeciej. Jedynie na marginesie wypada zauważyć, że przepis ten znajduje się poza rozdziałem 8 o.p., albowiem został on umieszczony w bezpośrednim sąsiedztwie regulacji dotyczącej materii, której przedawnienia dotyczy, co dodatkowo przemawia za wprowadzeniem postulowanego rozwiązania właśnie w obrębie art. 24 o.p., jednak kwestia ewentualnych zmian z pewnością wymaga szerszej dyskusji wśród przedstawicieli nauki.

\section{Bibliografia}

\section{Akty prawne}

Ustawa z dnia 26 lipca 1991 roku o podatku dochodowym od osób fizycznych, Dz.U. z 2019 r. poz. 1387, 1394, 1622, 1726 i 1835.

Ustawa z dnia 7 września 1991 roku o systemie oświaty, Dz.U. z 2016 r. poz. 1943.

Ustawa z dnia 2 kwietnia 1997 roku - Konstytucja Rzeczypospolitej Polskiej, Dz.U. Nr 78, poz. 483; z 2001 r. Nr 28, poz. 319; z 2006 r. Nr 200, poz. 1471; oraz z 2009 r. Nr 114, poz. 946.

Ustawa z dnia 29 sierpnia 1997 roku — Ordynacja podatkowa, Dz.U. z 2019 r. poz. 900 z późn. zm.

Ustawa z dnia 5 sierpnia 2015 roku o zmianie ustawy - Ordynacja podatkowa oraz niektórych innych ustaw, Dz.U. poz. 1197.

Ustawa z dnia 14 grudnia 2016 roku - Prawo oświatowe, Dz.U. z 2019 r. poz. 1148 z późn. zm.

Ustawa z dnia 14 grudnia 2016 roku - Przepisy wprowadzające ustawę - Prawo oświatowe, Dz.U. z 2017 r. poz. 60 z późn. zm.

\section{Literatura}

Adamiak B., [w:] B. Adamiak, J. Borkowski, R. Mastalski, J. Zubrzycki, Ordynacja podatkowa. Komentarz, Wrocław 2004.

Borszowski P., Działalność gospodarcza w konstrukcji prawnej podatku, Warszawa 2010.

Borszowski P., Pojęcie działalności gospodarczej w przepisach prawnopodatkowych, „Przegląd Podatkowy" 2007, nr 12. 
Damaz M., [w:] Ordynacja podatkowa. Komentarz, red. H. Dzwonkowski, Warszawa 2018.

Etel L., [w:] Ordynacja podatkowa. Komentarz, red. L. Etel, Warszawa 2017.

Etel L., [w:] Prawo podatkowe. Zarys wyktadu, red. L. Etel, Warszawa 2013.

Gomułowicz A., Ekspertyza na temat przedstawionego przez Prezydenta RP projektu ustawy o zmianie ustawy Ordynacja podatkowa w zakresie propozycji ujęcia art. 2 a o.p. (druk 3018), ,Zeszyty Prawnicze BAS" 2015, nr 2, poz. 46.

Gruszczyński B., [w:] S. Babiarz, B. Dauter, B. Gruszczyński, R. Hauser, A. Kabat, M. Niezgódka-Medek, Ordynacja podatkowa. Komentarz, Warszawa 2015.

Mastalski R., Prawo podatkowe, Warszawa 2018.

Safjan M., [w:] Konstytucja RP, t. 1. Komentarz do art. 1-86, red. M. Safjan, L. Bosek, Warszawa 2016.

Tuleja P., [w:] Konstytucja RP, t. 1. Komentarz do art. 1-86, red. M. Safjan, L. Bosek, Warszawa 2016.

Wronkowska S., Podstawowe pojęcia prawa i prawoznawstwa, Poznań 2005.

Wronkowska S., Zieliński M., Ziembiński Z., Zasady prawa. Zagadnienia podstawowe, Warszawa 1974.

Wronkowska S., Ziembiński Z., Zarys teorii prawa, Poznań 1997.

\section{Orzeczenia}

Orzeczenie Trybunału Konstytucyjnego z dnia 9 marca 1988 roku, U 7/87, OTK 1988, nr 1, poz. 1. Orzeczenie Trybunału Konstytucyjnego z dnia 20 grudnia 1994 roku, K 8/94, OTK 1994, nr 1, poz. 43.

Uchwała Naczelnego Sądu Administracyjnego (7) z dnia 6 listopada 2017 roku, II FPS 3/17, ONSA i WSA 2018, nr 2, poz. 21.

Uchwała Sądu Najwyższego z dnia 20 czerwca 2000 roku, I KZP 14/00, OSN 2000, nr 7-8, poz. 59.

Wyrok Naczelnego Sądu Administracyjnego z dnia 25 stycznia 2012 roku, II FSK 1345/10, LEX nr 1108976.

Wyrok Naczelnego Sądu Administracyjnego z dnia 7 lutego 2012 roku, II FSK 1323/10, LEX nr 1137498.

Wyrok Naczelnego Sądu Administracyjnego z dnia 3 września 2013 roku, II FSK 2208/12, „Monitor Podatkowy" 2013, nr 11 poz. 42.

Wyrok Trybunału Konstytucyjnego z dnia 25 listopada 1997 roku, K 26/97, OTK 1997, nr 5-6, poz. 64.

Wyrok Trybunału Konstytucyjnego z dnia 6 maja 1998 roku, K 37/97, OTK 1998, nr 3, poz. 33.

Wyrok Trybunału Konstytucyjnego z dnia 20 października 1998 roku, K 7/98, OTK 1998, nr 6, poz. 96.

Wyrok Trybunału Konstytucyjnego z dnia 17 maja 1999 roku, P 6/98, OTK 1999, nr 4, poz. 76.

Wyrok Trybunału Konstytucyjnego z dnia 21 września 1999 roku, K 6/98, OTK 1999, nr 6, poz. 117.

Wyrok Trybunału Konstytucyjnego z dnia 21 grudnia 1999 roku, K 22/99, OTK 1999, nr 7, poz. 166.

Wyrok Trybunału Konstytucyjnego z dnia 4 stycznia 2000 roku, K 18/99, OTK 2000, nr 1, poz. 1. Wyrok Trybunału Konstytucyjnego z dnia 18 grudnia 2000 roku, K 10/00, OTK 2000, nr 8, poz. 298.

Wyrok Trybunału Konstytucyjnego z dnia 7 lutego 2001 roku, K 27/00, OTK 2001, nr 2, poz. 29.

Wyrok Trybunału Konstytucyjnego z dnia 25 kwietnia 2001 roku, K 13/01, OTK 2001, nr 4, poz. 81. Wyrok Trybunału Konstytucyjnego z dnia 21 maja 2002 roku, K 30/01, OTK-A 2002, nr 3, poz. 32. 
Wyrok Trybunału Konstytucyjnego z dnia 22 lutego 2005 roku, K 10/04, OTK-A 2005, nr 2, poz. 17.

Wyrok Trybunału Konstytucyjnego z dnia 18 grudnia 2008 roku, K 19/07, OTK-A 2008, nr 10, poz. 182.

Wyrok Trybunału Konstytucyjnego z dnia 15 lipca 2013 roku, K 7/12, OTK-A 2013, nr 6, poz. 76. Wyrok Trybunału Konstytucyjnego z dnia 18 lipca 2013 roku, SK 18/09, OTK-A 2013, nr 6, poz. 80.

Wyrok Trybunału Konstytucyjnego z dnia 29 lipca 2014 roku, P 49/13, OTK-A 2014, nr 7, poz. 79. Wyrok Wojewódzkiego Sądu Administracyjnego w Gdańsku z dnia 8 stycznia 2008 roku, I SA/Gd 901/07, LEX nr 361965.

Wyrok Wojewódzkiego Sądu Administracyjnego w Gdańsku z dnia 21 grudnia 2010 roku, I SA/Gd 677/10, LEX nr 748000.

Wyrok Wojewódzkiego Sądu Administracyjnego w Olsztynie z dnia 19 kwietnia 2006 roku, I SA/ O1 98/06, LEX nr 283245.

Wyrok Wojewódzkiego Sądu Administracyjnego w Szczecinie z dnia 23 stycznia 2010 roku, I SA/ Sz 653/09, LEX nr 559567.

Wyrok Wojewódzkiego Sądu Administracyjnego we Wrocławiu z dnia 15 lutego 2018 roku, I SA/ Wr 462/17, LEX nr 2474926. 